\title{
Effect of partial whey protein depletion during membrane filtration on thermal stability of milk concentrates
}

\author{
I. R. T. Renhe* and M. Corredigt $t^{1,2}$ \\ *Instituto de Laticínios Cândido Tostes-Epamig, Juiz de Fora, Minas Gerais 36045-560, Brazil \\ †Department of Food Science, University of Guelph, Guelph, Ontario N1G 2W1, Canada
}

\begin{abstract}
Membrane filtration technologies are widespread unit operations in the dairy industry, often employed to obtain ingredients with tailored processing functionalities. The objective of this work was to better understand the effect of partial removal of whey proteins by microfiltration (MF) on the heat stability of the fresh concentrates. The micellar casein concentrates were compared with control concentrates obtained using ultrafiltration (UF). Pasteurized milk was microfiltered ( $80 \mathrm{kDa}$ polysulfone membrane) or ultrafiltered (30 $\mathrm{kDa}$ cellulose membrane) without diafiltration (i.e., no addition of water) to $2 \times$ and $4 \times$ concentration, based on volume reduction. The final concentrates showed no differences in $\mathrm{pH}$, casein micelle size, or mineral concentration in the serum phase. The micellar casein retentates (obtained by MF) showed a 20 and $40 \%$ decrease in whey protein concentration compared with the corresponding UF milk protein concentrates for $2 \times$ and $4 \times$ concentration, respectively. The heat coagulation time decreased with increasing protein concentration, regardless of the treatment; however, MF retentates showed a higher thermal stability than the corresponding UF controls. The average diameter for casein micelles increased after heating in UF but not MF concentrates. The turbidity (measured by light scattering) increased after heating, but to a higher extent for UF retentates than for MF retentates at the same protein concentration. It was concluded that the reduced amount of whey protein in the MF retentates caused a significant increase in the heat stability compared with the corresponding UF retentates. This difference was not due to ionic composition differences or $\mathrm{pH}$, but to the type and amount of complexes formed in the serum phase.
\end{abstract}

Key words: microfiltration, heat stability, milk protein

Received January 7, 2018.

Accepted March 24, 2018.

${ }^{1}$ Corresponding author: mcorredi@uoguelph.ca

${ }^{2}$ Current address: Gay Lea Foods Co-operative Ltd., 21 Speedvale Ave., Guelph, Ontario N1H 1J5, Canada.

\section{INTRODUCTION}

The use of concentrated milk protein ingredients has become increasingly widespread for high-protein beverages because of the high demand in the marketplace (Agarwal et al., 2015). Milk contains caseins and whey proteins, and these proteins have very different heat denaturation behavior. Whey proteins in their native form show a globular structure, which unfolds at temperatures $>62^{\circ} \mathrm{C}$ (Singh and Havea, 2003). Caseins, on the other hand, are relatively stable to heating in their monomeric form because of their flexible structure.

The interactions between whey proteins and caseins have been widely studied in skim milk and are affected by time, temperature, rate of heating, $\mathrm{pH}$, and protein concentration (Anema et al., 2006; Anema, 2009; Li et al., 2015). The complexes formed mostly with $\kappa-\mathrm{CN}$ and $\alpha_{S_{2}-}$ CN may be soluble in the serum or associated with the micelles, according to the $\mathrm{pH}$ of the initial milk (Alexander and Dalgleish, 2005; Dalgleish and Corredig, 2012). The details on the formation of soluble and colloidal heat denatured aggregates in milk concentrated by filtration are not fully understood. Concentration increases the amount of protein in the soluble phase and leads to calcium phosphate solubilization, with a consequent increase in the formation of unsedimentable protein and soluble aggregates (Ferrer et al., 2011; Li and Corredig, 2014).

In designing high protein milk beverages, concentrates obtained by membrane filtration are often used. Whereas with UF both caseins and whey proteins are concentrated in the retentate, when using larger pore size membranes, it is possible to selectively concentrate caseins while transmitting whey proteins in the permeate. Depending on the extent of diafiltration, it is possible to achieve up to $95 \%$ of serum protein removal (Nelson and Barbano, 2005). Because of their sensitivity to heat, whey protein removal has been proposed as a way to produce more heat-stable beverages (Sauer and Moraru, 2012) and a solution for shelf-stable highprotein beverages (Sauer and Moraru, 2012).

Studies have been conducted on the stability of reconstituted dispersions of micellar micellar casein (from 
powders with less than $5 \%$ of total protein being whey proteins). These dispersions have been studied at different $\mathrm{pH}$ values, with variable calcium concentration and colloidal calcium distribution, with or without chelators [e.g., uridine monophosphate, disodium hydrogen phosphate, sodium hexametaphosphate, and trisodium citrate (de Kort et al., 2012; Sauer and Moraru, 2012)]. These studies have demonstrated poor heat stability of protein concentrates at $\mathrm{pH}$ lower than 6.9 , with visible aggregation after sterilization, both by UHT or retort processes (Sauer and Moraru, 2012). Whereas at pH 6.9 the average casein micelle size increases after heating, this is not the case at higher $\mathrm{pH}$ (Sauer and Moraru, 2012). The positive effect of increasing the $\mathrm{pH}$ in the range of 6.7 to 7.3 on the heat stability of micellar casein concentrates was also reported by de Kort et al. (2012), who also demonstrated that calcium chelators increase heat stability of the concentrates to varying degrees depending on the chelator type and concentration.

As most of the research reported on the heat stability of milk concentrates has been conducted on reconstituted suspensions, in this research, it is hypothesized that the results may not apply to fresh concentrates. Profound changes occur in the calcium and phosphate equilibrium during drying and reconstitution. The objective of this work was to understand the effect of a reduction in whey protein in the heat stability of milk concentrates. The use of microfiltration (MF) to reduce the concentration of whey proteins and to increase the casein-to-whey ratio in the retentate may provide a solution to problems related to heat stability of milk concentrates, as well as an opportunity to create novel functional ingredients. The heat stability of fresh concentrates with a reduced concentration of whey proteins (referred to as MF retentates) was then compared with that of concentrates prepared by UF, still containing the original whey-to-protein ratio. It is important to note that by avoiding the diafiltration step during concentration, it was possible to maintain a comparable ionic composition in the serum phase among the fresh concentrates.

\section{MATERIALS AND METHODS}

\section{Sample Preparation}

Pasteurized skim milk (Sealtest/Agropur, supplied by Crown Dairy Ltd., Guelph, Canada) was $4 \times$ concentrated in a plate-and-frame membrane system (PUROSEP LT-2, SmartFlow Technologies, Apex, NC) as previously described (Li et al., 2015). The membranes used were either 30 or $80 \mathrm{kDa}$ molecular cutoff. The plate-and-frame system differs from common spiralwound systems by allowing low transmembrane pressure and better molecular weight cut off due to low fouling of the membranes. Therefore, it was possible to achieve a reduction in the whey protein-to-casein ratio with a $80 \mathrm{kDa}$ cutoff membrane. Samples obtained were referred as UF or MF retentates. Samples were collected at $2 \times$ and $4 \times$ concentration in both processes, based on volume reduction, by measuring the volume of permeate. Retentates concentrated $4 \times$ were also diluted back to $2 \times$ concentration with permeate obtained by UF. With this procedure the samples obtained had the same protein volume fraction, but with a different ratio of casein to whey proteins. Using UF permeate in the dilution experiments, it was possible to maintain a similar ionic composition of the serum phase for all the samples.

In total, 7 samples were examined: skim milk control; microfiltered milk $2 \times$ and $4 \times$ concentrated $(\mathbf{2} \times \mathbf{M F}$; $4 \times \mathrm{MF})$; UF milk $2 \times$ and $4 \times$ concentrated $(\mathbf{2} \times \mathbf{U F}$; $4 \times \mathbf{U F})$; and $4 \times \mathrm{MF}$ and UF rediluted to $2 \times$ with $\mathrm{UF}$ permeate $(\mathbf{4} \times \mathbf{M F D} ; \mathbf{4} \times \mathbf{U F D})$. In separate experiments, the concentrates were also subjected to dialysis with UF permeate at $4^{\circ} \mathrm{C}$ overnight to further equilibrate the serum ionic composition. A cellulose dialysis membrane (Fisher Scientific, Whitby, ON, Canada) with a molecular mass cutoff of 6 to $8 \mathrm{kDa}$ was used. Dialysis was conducted at a ratio of $1 \mathrm{~L}$ of permeate per $50 \mathrm{~mL}$ of sample.

\section{Heat Treatment and Heat Stability}

The thermal stability of retentates was determined by heat coagulation time (HCT), defined as the time required during heating at $120^{\circ} \mathrm{C}$ to induce visible coagulation. The system used was a silicone oil bath (Haake AC200, Thermo Fisher Scientific, Newington, NH) fitted with a custom-made circulation device. Threemilliliter aliquots were transferred to a heat-resistant screw-cap test tube and immersed in the oil bath at $120^{\circ} \mathrm{C}$ (Eshpari et al., 2014). The samples were kept under agitation, and the elapsed time between the immersion and the first visible precipitation was recorded as the HCT.

To further characterize the effect of heating on the various concentrates, aliquots $(9 \mathrm{~mL})$ of retentate were transferred to a glass tube and heated at $120^{\circ} \mathrm{C}$ for 10 min in the silicone oil bath (see above). The heating time of 10 min was arbitrarily chosen, as, at this time, most samples did not show coagulation and could then be further analyzed. After heating, the samples were cooled immediately to room temperature by immersion in an ice bath. 


\section{Sample Characterization}

Total solids were determined by drying approximately $2 \mathrm{~g}$ of sample in an aluminum dish. The samples were overnight dried at $105^{\circ} \mathrm{C}$ in a gravity-flow convection oven over pre-dried sand (Fisher Scientific, Pittsburgh, $\mathrm{PA}$ ). The $\mathrm{pH}$ of the retentates was measured at $25^{\circ} \mathrm{C}$, under agitation, using an Accumet $\mathrm{pH}$ meter (Fisher Scientific), calibrated before use.

Total protein concentration was measured by Dumas (Leco FP-528, Leco Corp., St. Joseph, MI) using a conversion factor of 6.38 to convert the nitrogen concentration into protein. The soluble fraction was obtained by ultracentrifugation $\left(62,000 \times g\right.$ for $1 \mathrm{~h}$ at $\left.20^{\circ} \mathrm{C}\right)$. The colorimetric DC protein assay method composed by an alkaline copper tartrate solution and a dilute Folin Reagent (Bio-Rad, Mississauga, ON, Canada) was used to measure the protein in the centrifugal supernatants. The whey protein concentration was measured by HPLC (Thermo Instruments Canada Inc., Mississauga, ON, Canada). A $20-\mu \mathrm{L}$ aliquot of supernatant was loaded onto a Nova-Pak C18 column (15 mm length $\times 3.9 \mathrm{~mm}$ i.d., with a C18 guard column) and eluted in a $1 \mathrm{~mL} / \mathrm{min}$ flow gradient of solvent $\mathrm{A}(0.1 \% \mathrm{vol} /$ vol trifluoroacetic) and solvent B [acetonitrile, MilliQ water, and trifluoroacetic in a ratio 900:100:1 ( $\mathrm{vol} / \mathrm{vol} /$ vol)]. The gradient started with $2 \%$ eluent $\mathrm{B}$, increasing to $70 \% \mathrm{~B}$ in $40 \mathrm{~min}$, achieving $100 \% \mathrm{~B}$ in $41 \mathrm{~min}$, and kept at $100 \%$ until 47 min. Eluted peaks were detected at $280 \mathrm{~nm}$, and quantification was possible using purified protein standards.

\section{Viscosity}

Viscosity was measured using a controlled stress rheometer (Paar Physica MC 301, Anton Paar, Graz, Austria) using cone and plate geometry, with a set gap of $0.51 \mathrm{~mm}$. The temperature of the system was controlled at $25^{\circ} \mathrm{C}$. The milk retentate samples were subjected to a shear sweep test from 10 to $300 \mathrm{~s}^{-1}$, and values at $100 \mathrm{~s}^{-1}$ were arbitrarily chosen to determine statistical differences.

\section{Light Scattering}

Particle size distribution was determined by dynamic light scattering (Zetasizer Nano, Malvern Instruments, Worcestershire, UK). The samples were extensively diluted $(1: 1,000)$ with filtered $(0.22 \mu \mathrm{m}$ PVDF filters, Fisher Scientific) permeate from UF.

Transmission diffusing wave spectroscopy was employed to measure the turbidity in situ without dilution. The photon transport mean free path $\left(1^{*}\right)$, which is defined as the length scale over which the scattered light has been totally randomized (Alexander and Dalgleish, 2005; Nicolai, 2007), was measured. The $1^{*}$ depends on physical properties of the scattering particles, particles' concentration, the refractive index contrast, as well as the inter-particle spatial correlation (Alexander et al., 2006).

For the analysis, a solid-state laser light with a wavelength of $532 \mathrm{~nm}$ and a power of $350 \mathrm{~mW}$ (Verdi V2 from Coherent, Santa Clara, CA) was used to illuminate the samples held in a 5-mm path length optical glass cuvette (Hellma Canada Ltd., Concord, ON, Canada) at $25^{\circ} \mathrm{C}$. The viscosity and refractive index of the continuous phase used to calculate the radius were $1.021 \times 10^{-3} \mathrm{~Pa} \cdot \mathrm{s}$ and 1.34 , respectively (Alexander and Dalgleish, 2005; Alexander et al., 2006).

\section{Total, Soluble, and Diffusible Calcium and Phosphate}

For total calcium, milk samples were precipitated using $1 \mathrm{M} \mathrm{HCl}$ and centrifuged in 2-mL centrifuge tubes for 15 min at $4,500 \times g$ at $22^{\circ} \mathrm{C}$ (Eppendorf centrifuge, Brinkmann Instruments Ltd., Mississauga, ON, Canada), and the clear supernatant was used for analysis. Soluble fractions were analyzed from the supernatants after centrifugation at $62,000 \times g$ for $1 \mathrm{~h}$ at $20^{\circ} \mathrm{C}$. The diffusible calcium and phosphate was obtained after UF of soluble phases in concentrators with molecular weight cutoff of $10 \mathrm{kDa}$ (Corning Spin-X UF, Fisher Scientific, Fair Lawn, NJ), at 5,000 $\times g$ for $30 \mathrm{~min}$ at $22^{\circ} \mathrm{C}$. For total and soluble phosphate analysis, $0.5 \mathrm{~mL}$ of original samples and soluble phase were incinerated at $500^{\circ} \mathrm{C}$ for $8 \mathrm{~h}$ and then solubilized with $1 \mathrm{~mL}$ of $1 \mathrm{M}$ nitric acid before dilution in water.

An Advanced Compact Ion chromatography ( $\Omega$ Metrohm ion analysis, Metrohm Ltd., Herisau, Switzerland) with a conductivity detector was used to measure calcium and phosphate (Zhao and Corredig, 2015). For calcium determination, a cation column (Metrosep C4/150, Metrohm AG) was employed. Samples were eluted at a flow rate of $0.9 \mathrm{~mL} / \mathrm{min}$ with $0.7 \mathrm{~m} M$ dipicolinic acid and $1.7 \mathrm{mM} \mathrm{HNO}_{3}$ as the mobile phase. For the determination of phosphate fractions, HPLCgrade water was used as acceptor solution and the samples were eluted on an anion column (Metrosep A Supp5-150/4.0, Metrohm AG). Samples were eluted at a flow rate of $0.5 \mathrm{~mL} / \mathrm{min}$ of $1.0 \mathrm{mM}$ sodium hydrogen carbonate and $3.2 \mathrm{mM}$ sodium carbonate (Fisher Scientific).

\section{Characterization of Soluble Protein Aggregates}

Soluble protein aggregates were characterized by size exclusion chromatography using an ÄKTA purifier 10 
Table 1. Composition (mean $\pm \mathrm{SD}$ ) of fresh retentates, at $2 \times$ and $4 \times$ concentration; $4 \times$ microfiltered (MF) and UF concentrates were also diluted back to $2 \times$ using UF permeate (MFD and UFD, respectively)

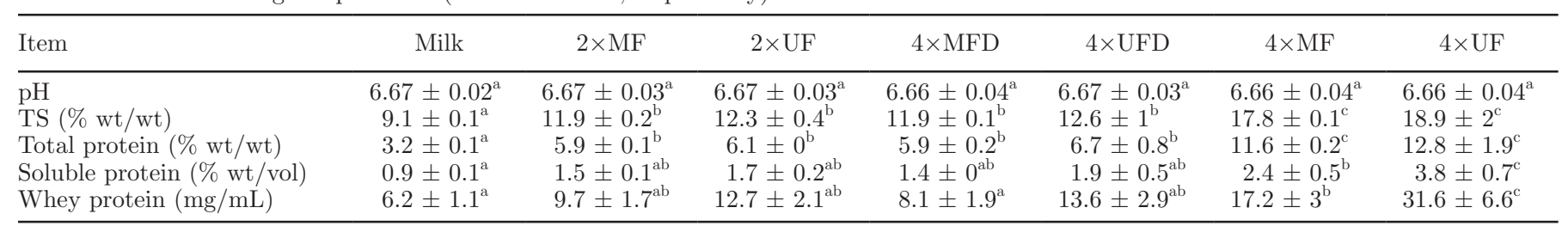

${ }^{a-c}$ Within a row, different superscripts indicate significant differences $(P<0.05)$.

system (GE Healthcare, Uppsala, Sweden) and a column (AA Pharmacia XK 16/70) of $67 \mathrm{~cm}$ bed height packed with S-500 Sephacryl high resolution gel, with a nominal fractionation range of 40 to $20,000 \mathrm{kDa}(\mathrm{Am}-$ ersham Biosciences Inc., Baie-D'Urfé, Quebec, Canada) as previously described ( $\mathrm{Li}$ et al., 2015). The soluble phase was obtained through centrifugation at $62,000 \times$ $g$ for $1 \mathrm{~h}$ at $20^{\circ} \mathrm{C}$. Fractions of $10 \mathrm{~mL}$ were collected each 10 min from 40 to 170 min for further analysis of the differences in the type and composition of the soluble aggregates through electrophoresis. The fractions were freeze-dried and then diluted in $1 \mathrm{~mL}$ of sample buffer without $\beta$-mercaptoethanol (Tris-Cl base, glycerol, SDS, bromophenol blue). The electrophoresis analysis of the peak eluted between 60 and 90 min was conducted under both reducing (with $\beta$-mercaptoethanol) and nonreducing conditions. Sodium dodecyl sulfatePAGE was performed using a Bio-Rad electrophoresis unit (Bio-Rad Power Pac HC, Mississauga, ON, Canada) at $175 \mathrm{~V}$ for $50 \mathrm{~min}$. The resolving gel contained $15 \%$ acrylamide and the stacking gel contained $4 \%$ acrylamide. Aliquots of $5 \mu \mathrm{L}$ of $1 \%$ (wt/wt) standard solutions (sodium caseinate and whey protein isolate with $85 \%$ protein) were loaded onto the gels. For the samples, $10 \mu \mathrm{L}$ of the $4 \times$ samples or $20 \mu \mathrm{L}$ of milk and $2 \times$ samples were loaded on the nonreducing analysis; and $8 \mu \mathrm{L}$ of the $4 \times$ samples or $16 \mu \mathrm{L}$ of milk and $2 \times$ samples were loaded on the reducing analysis. The gels were stained with Coomassie blue $(0.18 \%$ wt/vol $)$, destained in multiple steps with solutions of methanol, acetic acid, and Milli-Q water (45:10:45), scanned (BioRad Laboratories), and then analyzed using Image Lab software (Bio-Rad, version 5.2.1).

\section{Statistical Analysis}

The experiment was carried out in triplicate (i.e., 3 separate milk batches). Statistical significances were evaluated using ANOVA at $P<0.05$ and $t$-test. The mean values were compared using Tukey test, with all data processed using Statistica 12 software (Statsoft, TIBCO, Palo Alto, CA).

\section{RESULTS AND DISCUSSION}

\section{Characterization of the Concentrates}

Table 1 summarizes the amount of solids, protein, and soluble protein, including native whey protein, present in control milk as well as in the various fresh concentrates prepared by MF and UF. Samples of $4 \times$ $\mathrm{MF}$ and UF concentrates rediluted with UF permeate to $2 \times$ concentration are also shown in Table 1 and are indicated as MFD and UFD.

The composition of the concentrates was measured before and after dialysis against UF permeate and no statistically significant differences were present between the corresponding samples. This result suggests that, because of the absence of diafiltration in these experiments, there were no changes in the composition of the soluble phase.

As shown in Table 1, no difference was observed in $\mathrm{pH}$ between all the concentrates. This is in full agreement with what was previously reported for UF concentrates when diafiltration is not performed during concentration (Sandra et al., 2011). As pH is an important factor determining changes in heat-induced interactions between proteins, a comparable value of $\mathrm{pH}$ is critical to be able to study the effect of protein composition in MF and UF retentates.

In addition, no significant differences were observed in both protein and total solids between samples at the same volume concentration; however, differences were present in the soluble fraction and whey protein concentration as a result of the removal of whey proteins by MF. At the $2 \times$ concentration, no difference was observed in the amount of soluble protein for UF and MF milk, whereas the reduction of whey protein was statistically significant in the $4 \times$ concentrates.

All retentates showed no significant differences in the apparent diameter of casein micelles when measured by dynamic light scattering after dilution in permeate. The casein micelles showed an average diameter of about $170 \mathrm{~nm}$ (Table 2). Values of turbidity increased with increasing the casein micelles volume fraction, as clearly shown in Table 2 . The values of turbidity were 
Table 2. Apparent diameter (mean $\pm \mathrm{SD}$ ) of casein micelles, measured by dynamic light scattering, and turbidity, measured by diffusing wave spectroscopy, for fresh UF and microfiltered (MF) retentates, at $2 \times$ and $4 \times$ volume fraction, as well as samples rediluted with UF permeate from $4 \times$ to $2 \times$ concentration (MFD and UFD)

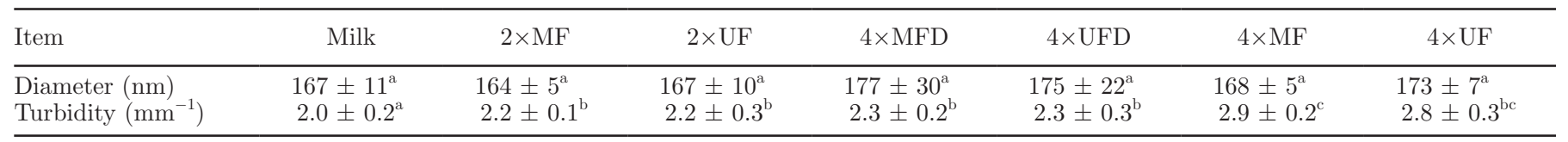

${ }^{\mathrm{a}-\mathrm{c}}$ Within a row, different superscripts indicate significant differences $(P<0.05)$.

the highest for $4 \times \mathrm{MF}$ concentrates. No differences were present in the turbidity parameter, nor the size, in microfiltered retentates compared with UF retentates at the same volume fraction. In all cases at $2 \times$ concentration the turbidity was about $2.2 \mathrm{~mm}^{-1}$, even for those samples after redilution with milk permeate.

Total calcium and phosphate were significantly different between samples at different concentrations, in agreement with previous work (Nair et al., 2013) but not among the groups with the same concentration factor. It is important to note that only one-third of the total calcium in milk is present in the soluble phase (Gaucheron, 2005), so most of the calcium is kept in the retentates. Within a concentration, all the samples presented similar calcium and phosphate contents, both for total as well as soluble (Table 3). Regardless of concentration, no differences were observed in soluble (present in the supernatant after centrifugation) and diffusible calcium or phosphate, all in accordance with the absence of diafiltration. Values of diffusible phosphate were similar for all samples (Table 3). However, higher values of soluble phosphate were present in $4 \times$ concentrated samples, compared with the skim milk control. The higher soluble phosphate may be due to a higher concentration of unsedimentable caseins with concentration.

Samples were also analyzed after equilibration by dialysis with UF permeate. In this case also, no significant differences were present in the calcium and phosphate composition of the serum phase (data not shown).

The data shown in Tables 1 and 3 demonstrate that 3 of the most important factors affecting heat stability of milk (Singh, 2004), which are pH, calcium, and phos- phate, were comparable within the $2 \times$ and $4 \times$ treatments. This will allow for a direct comparison of heat stability behavior between UF and MF retentates. This constitutes an important point of the present study, as often this is not the case in the literature when comparing reconstituted concentrates.

\section{Heat Stability of the Concentrates}

As shown in Table 4, in all cases, the HCT was $>30$ min. Heat coagulation time for skim milk control was around $60 \mathrm{~min}$, in accordance with an earlier report for milk at $\mathrm{pH} 6.7$ (O'Connell and Fox, 2003). It is known that $\mathrm{HCT}$ decreases with protein concentration (Singh, 2004). For the UF samples, the coagulation time decreased to 37 and $28 \mathrm{~min}$ for $2 \times \mathrm{UF}$ and $4 \times \mathrm{UF}$ concentrates, respectively. When the $4 \times$ concentrate was re-diluted to a $2 \times$ concentrate with permeate $(4 \times \mathrm{UFD})$, the HCT returned to the values of the corresponding $2 \times \mathrm{UF}$ concentrate, indicating that, with all the other conditions being comparable, only the protein concentration has an effect on heat stability. A similar trend was also noted for the MF samples; however, in this case, all the minimum coagulation times were significantly higher than those of the corresponding UF concentrates. It was possible then to conclude that the reduced ratio between whey proteins and caseins in micellar casein concentrates caused a significant increase in the heat stability of the retentates when compared with control milk protein concentrates.

As previously mentioned, this difference was not due to soluble calcium and phosphate composition differences, nor to differences in $\mathrm{pH}$. The $4 \times \mathrm{MF}$ retentates

Table 3. Composition (mean $\pm \mathrm{SD}$ ) of $\mathrm{Ca}$ and inorganic $\mathrm{P}\left(\mathrm{P}_{\mathrm{i}}\right)$ in the retentates and their corresponding soluble and diffusible phases ${ }^{1}$

\begin{tabular}{|c|c|c|c|c|c|c|c|}
\hline Item $(\mathrm{m} M)$ & Milk & $2 \times \mathrm{MF}$ & $2 \times \mathrm{UF}$ & $4 \times \mathrm{MFD}$ & $4 \times \mathrm{UFD}$ & $4 \times \mathrm{MF}$ & $4 \times \mathrm{UF}$ \\
\hline Ca soluble & $10.5 \pm 1.5^{\mathrm{a}}$ & $11.5 \pm 1.8^{\mathrm{a}}$ & $12.2 \pm 1.9^{\mathrm{a}}$ & $12.6 \pm 2.4^{\mathrm{a}}$ & $12.7 \pm 2^{\mathrm{a}}$ & $12.4 \pm 3.1^{\mathrm{a}}$ & $13.1 \pm 2.9^{\mathrm{a}}$ \\
\hline Ca diffusible & $7.5 \pm 1.7^{\mathrm{a}}$ & $7.5 \pm 2.1^{\mathrm{a}}$ & $7.1 \pm 1.7^{\mathrm{a}}$ & $6.6 \pm 1.9^{\mathrm{a}}$ & $7.1 \pm 1.6^{\mathrm{a}}$ & $6.7 \pm 1.3^{\mathrm{a}}$ & $7.0 \pm 1.7^{\mathrm{a}}$ \\
\hline $\mathrm{P}_{\mathrm{i}}$ soluble & $14.2 \pm 1.5^{\mathrm{a}}$ & $16.0 \pm 0.5^{\mathrm{ab}}$ & $16.3 \pm 0.6^{\mathrm{ab}}$ & $15 \pm 2.7^{\mathrm{ab}}$ & $16.9 \pm 1.1^{\mathrm{ab}}$ & $17.2 \pm 1.9^{\mathrm{b}}$ & $17.5 \pm 1.2^{\mathrm{b}}$ \\
\hline $\mathrm{P}_{\mathrm{i}}$ diffusible & $9.2 \pm 1.0^{\mathrm{a}}$ & $9.2 \pm 1.5^{\mathrm{a}}$ & $9.4 \pm 1.1^{\mathrm{a}}$ & $8.8 \pm 1.7^{\mathrm{a}}$ & $8.9 \pm 1.5^{\mathrm{a}}$ & $8.5 \pm 1.4^{\mathrm{a}}$ & $8.5 \pm 1.8^{\mathrm{a}}$ \\
\hline
\end{tabular}

${ }^{\mathrm{a}-\mathrm{d}}$ Within a row, different superscripts indicate significant differences $(P<0.05)$.

${ }^{1}$ Microfiltered milk $2 \times$ and $4 \times$ concentrated $(2 \times$ MF; $4 \times$ MF $)$; UF milk $2 \times$ and $4 \times$ concentrated $(2 \times$ UF; $4 \times \mathrm{UF}) ;$ and $4 \times$ MF and UF rediluted to $2 \times$ with UF permeate $(4 \times \mathrm{MFD} ; 4 \times \mathrm{UFD})$. 
contained $17 \pm 3 \mathrm{mg} / \mathrm{mL}$ of whey proteins, about $40 \%$ less whey proteins than the $4 \times \mathrm{UF}$ control retentates (Table 1 ). The $2 \times$ concentrates prepared with MF, containing approximately $20 \%$ less whey proteins than UF control, showed an increase in the HCT of about 11 min. A $4 \times$ concentrate prepared by MF showed statistically similar heat stability to that of a $2 \times \mathrm{UF}$ concentrates, with HCT of about 38 min.

These results are in contrast with data published in a previous study, whereby concentrates heated at a similar $\mathrm{pH}$, but with lower protein contents than those of the current work, showed instability in a broad range of heating treatments (Sauer and Moraru, 2012). In other words, in previous studies micellar casein concentrates were reconstituted to $8 \%$ (wt/vol) protein, adjusted to different $\mathrm{pH}$ values from 6.5 to 7.3 , and subjected to heat treatments at temperatures from 110 to $150^{\circ} \mathrm{C}$. Poor heat stability was reported at $\mathrm{pH}$ lower than 6.9 , with visible aggregation after heating at 110 and $120^{\circ} \mathrm{C}$, and complete coagulation for temperatures higher than $130^{\circ} \mathrm{C}$ (Sauer and Moraru, 2012). Another study using fresh micellar casein fractions, with protein concentrations between 5 and 10\%, showed significant increases in viscosity and visible aggregation after treatment with UHT or retorting regimens (Beliciu et al., 2012).

The cause of the discrepancy in the results is due to the use of reconstituted powders, which have a dramatically different processing history, as well as the use of extensively diafiltered fresh retentates. Diafiltration, the addition of water during concentration, significantly alters the salt balance of the system, resulting in losses of colloidal calcium ions and compositional changes in the serum phase, with consequent decreased stability of casein micelles (Sikand et al., 2013; Li and Corredig, 2014). The original $\mathrm{pH}$ of the samples after redilution was higher (7.1) than what was observed in this study (6.7; Sauer and Moraru, 2012). The initial values for total and soluble calcium and phosphate concentrations were also much lower compared with the values measured in the present study (Table 3). This hypothesis is also supported by previous work (Eshpari et al., 2014) that showed that milk concentrates (obtained with diafiltration) reconstituted to $5 \%$ (wt/wt solids) have short HCT. On the other hand, reconstituted powders obtained from concentrates where only UF was applied showed high heat stability, but at a higher $\mathrm{pH}$ than that employed in this study (Eshpari et al., 2014).

\section{Characterization of the Heat-Induced Aggregates}

To better understand the changes occurring during high temperature heating in the soluble phase, concentrates were heated at $120^{\circ} \mathrm{C}$ for $10 \mathrm{~min}$ and subsequently characterized for viscosity, apparent particle size and type, and amount of soluble proteins present. Figure 1 shows the differences in apparent particle diameter and turbidity for the retentates before and after heat treatment. Only the $4 \times \mathrm{UF}$ retentates showed a significant increase of casein micelle apparent diameter after heating. On the other hand, the turbidity parameter $1 / 1^{*}$, measured by diffusing wave spectroscopy, increased in all the samples after heating. The $4 \times \mathrm{UF}$ presented the highest turbidity and was different from all the other samples. In addition, $4 \times \mathrm{MF}$ concentrates showed a $1 / 1^{*}$ value comparable to that of $2 \times$ concentrates. All results pointed to the importance of the whey proteinto-casein ratio to the heat stability and functional properties of the retentates.

The viscosity of the various retentates was measured and showed an increase with concentration, in agreement with the literature (Walstra et al., 2006; Nair et al., 2013, 2014; Figure 2). All the samples presented shear thinning behavior to different degrees both before and after heating. For comparison, the values of viscosity measured at $100 \mathrm{~s}^{-1}$ are summarized in Figure 3, for all concentrates before and after heating at $120^{\circ} \mathrm{C}$ for $10 \mathrm{~min}$. Retentates prepared to $2 \times$ concentration did not differ from milk regarding viscosity and showed no significant differences in apparent viscosity regardless of processing conditions (MF, UF, or $4 \times$ rediluted with permeate, MFD and UFD). Similar behavior was observed with heating. On the other hand, $4 \times$ concentrates showed a higher viscosity than $2 \times$ concentrates, as previously reported (Nair et al., 2014), but no differences between samples at same volume fraction. It was concluded that the removal of whey proteins did not affect viscosity.

The soluble fraction of the various retentates was separated by centrifugation and analyzed to determine potential differences in the distribution of protein in

Table 4. Heat stability (mean $\pm \mathrm{SD}$ ) of retentates measured as heat coagulation time $(\mathrm{HCT})$ at $120^{\circ} \mathrm{C}^{1}$

\begin{tabular}{|c|c|c|c|c|c|c|c|}
\hline Sample & Milk & $2 \times \mathrm{MF}$ & $2 \times \mathrm{UF}$ & $4 \times \mathrm{MFD}$ & $4 \times \mathrm{UFD}$ & $4 \times \mathrm{MF}$ & $4 \times \mathrm{UF}$ \\
\hline HCT (min) & $64 \pm 6^{\mathrm{a}}$ & $49 \pm 4^{\mathrm{b}}$ & $38 \pm 2^{\mathrm{c}}$ & $52 \pm 6^{\mathrm{b}}$ & $36 \pm 2^{\mathrm{c}}$ & $39 \pm 1^{\mathrm{c}}$ & $28 \pm 3^{\mathrm{d}}$ \\
\hline
\end{tabular}




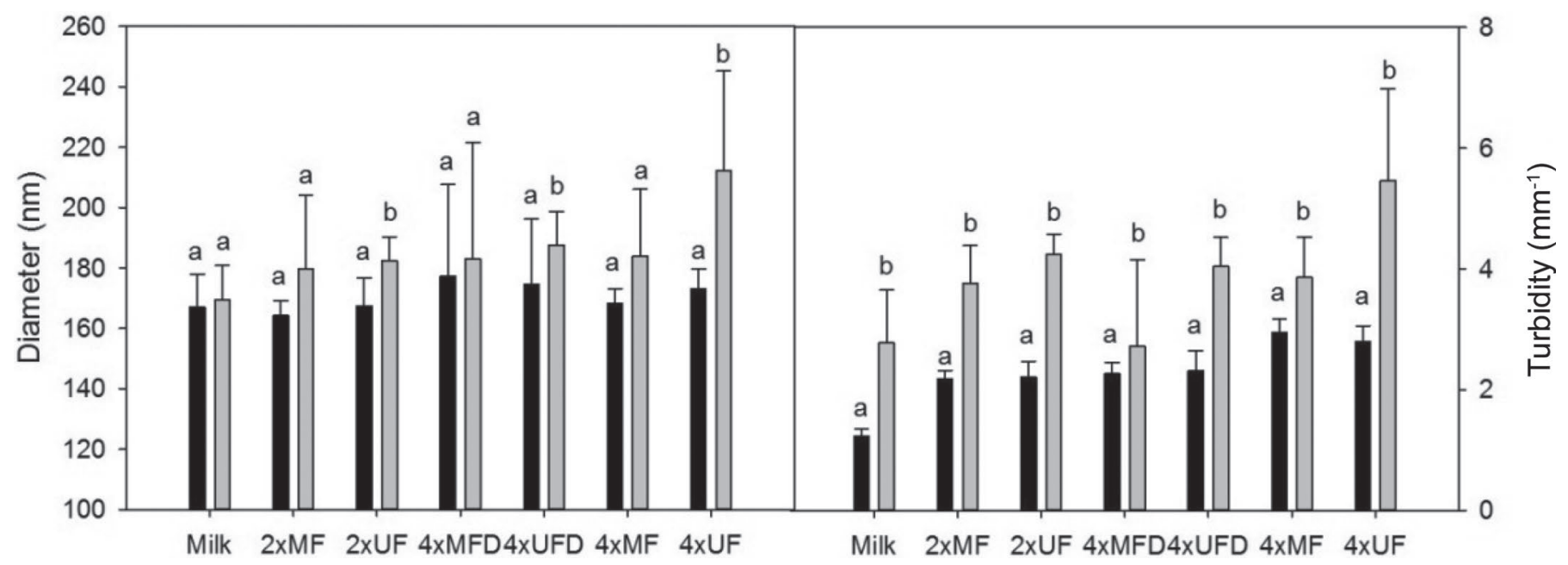

Figure 1. Apparent diameter, measured by dynamic light scattering, and turbidity, measured by diffusing wave spectroscopy, for unheated (black) and heat-treated (gray) samples. Different letters indicate a statistical difference within sample after heating $(P<0.05)$. Error bars indicate SD.

the supernatant. Size exclusion chromatography has been previously employed to determine differences in size and composition of unsedimentable aggregates after heating for skim milk as well as milk protein concentrates (Donato and Dalgleish, 2006; Donato et al., 2007; Li et al., 2015). The difference in distribution of unsedimentable aggregates present in supernatants of $2 \times$ and $4 \times \mathrm{MF}$ and UF samples has never been reported. Figure 4 illustrates the difference in the elution of the unsedimentable protein fraction for unheated and heated concentrates. The various fractions were identified as previously reported (Donato and Dalgleish, 2006; Li et al., 2015). Supernatants isolated from unheated concentrates (Figure 4A) showed a large peak at 110 min elution time, corresponding to the elution of native whey proteins (Donato et al., 2007).

A clear difference was observed in the peak size for the native whey protein for $4 \times \mathrm{UF}$, with a lower peak for $4 \times \mathrm{MF}$, confirming the decrease in the amount of whey protein in these samples. Furthermore, the elution of this peak for $4 \times \mathrm{MF}$ was comparable to that of the $2 \times$ samples. After heating at $120^{\circ} \mathrm{C}$ for $10 \mathrm{~min}$ (Figure $4 \mathrm{~B}$ ), there was a decrease of the native whey protein and most of the protein material eluted earlier, between 60 and $90 \mathrm{~min}$. This change in elution corresponded to a change in the population of the unsedimentable aggregates. The size of the eluted peak has been previously shown to increase with concentration

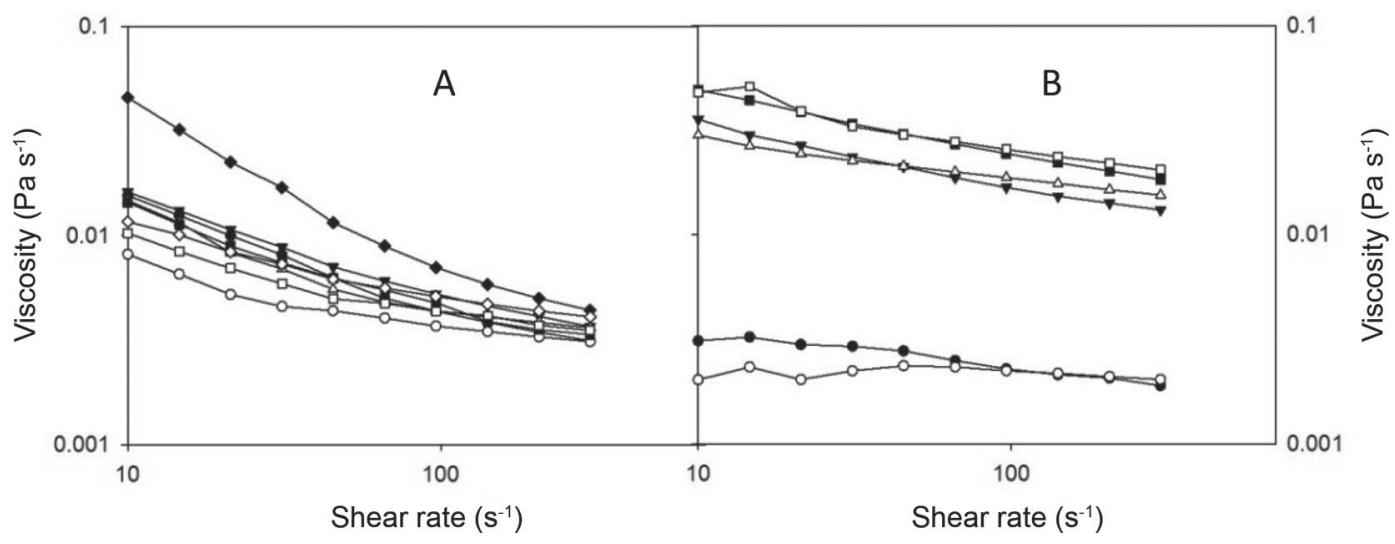

Figure 2. Viscosity of samples versus shear rate before heating (open symbols) and after heat treatment of 10 min at $120^{\circ} \mathrm{C}$ (filled symbols) for samples at $2 \times$ concentration (A) and milk and $4 \times$ concentration (B). (A) $\bigcirc 2 \times$ MF; $\Delta 2 \times$ UF; $\square 4 \times$ MFD; $\diamond 4 \times$ UFD. (B) $\bigcirc$ Milk; $\Delta 4 \times$ MF; $\square 4 \times \mathrm{UF}$. Microfiltered milk $2 \times$ and $4 \times$ concentrated $(2 \times \mathrm{MF} ; 4 \times \mathrm{MF}) ; \mathrm{UF}$ milk $2 \times$ and $4 \times$ concentrated $(2 \times \mathrm{UF} ; 4 \times \mathrm{UF}) ;$ and $4 \times \mathrm{MF}$ and UF rediluted to $2 \times$ with UF permeate $(4 \times \mathrm{MFD} ; 4 \times \mathrm{UFD})$. 


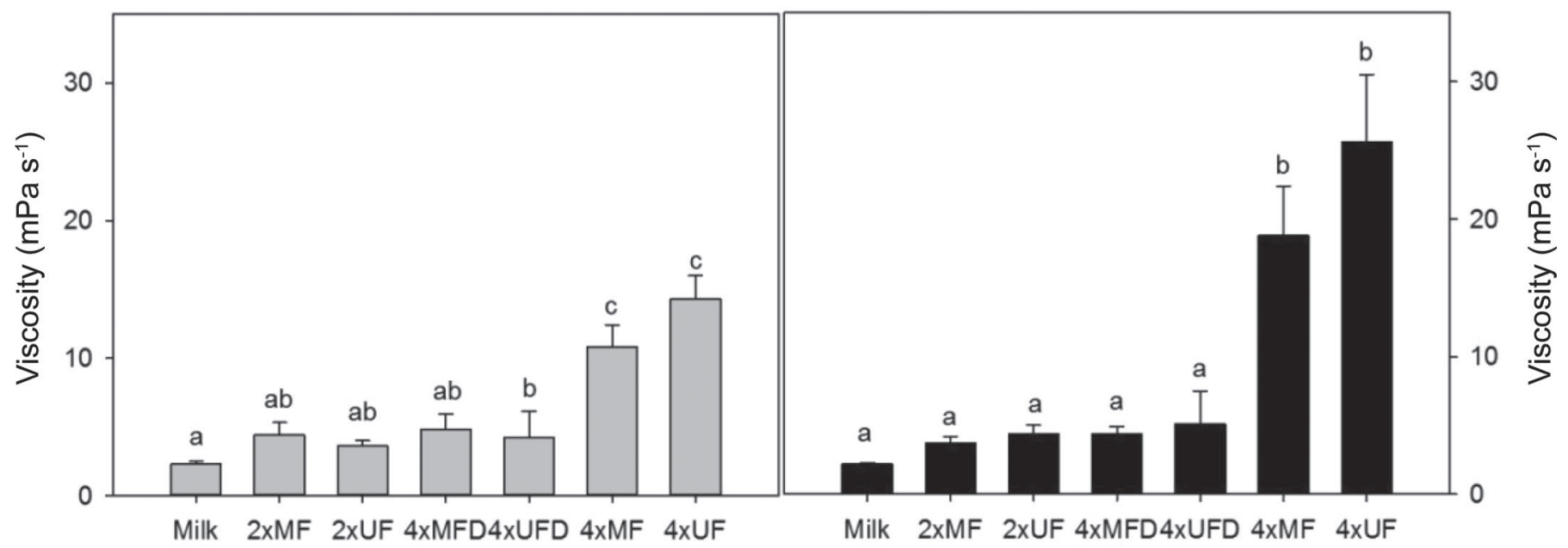

Figure 3. Viscosity of samples at a shear rate of $100 \mathrm{~s}^{-1}$ before (gray) and after heat treatment of 10 min at $120^{\circ} \mathrm{C}$ (black). Microfiltered milk $2 \times$ and $4 \times$ concentrated $(2 \times \mathrm{MF} ; 4 \times \mathrm{MF})$; UF milk $2 \times$ and $4 \times$ concentrated $(2 \times \mathrm{UF} ; 4 \times \mathrm{UF})$; and $4 \times$ MF and UF rediluted to $2 \times$ with UF permeate $(4 \times \mathrm{MFD} ; 4 \times \mathrm{UFD})$. Error bars indicate SD; different letters $(\mathrm{a}-\mathrm{c})$ indicate a statistical difference $(P<0.05)$.

(Li et al., 2015). The difference in elution depicted in Figure 4 clearly demonstrated that the supernatant of MF retentates had a lower extent of unsedimentable aggregates compared with the supernatant of corresponding UF retentate.

At $2 \times$ concentration, samples presented a similar elution profiles with a small shift for the MF supernatant toward a later elution, which suggests the presence of smaller aggregates in MF than in UF. These results may be explained considering that aggregates are formed by interactions of whey proteins and fractions of casein, mainly $\kappa-\mathrm{CN}$, and that they are a function of protein concentration (Guyomarc'h et al., 2003; Donato et al., 2007).

At $4 \times$ concentration, a much larger population of aggregates eluted earlier in the chromatography in the supernatant of UF concentrate compared with that of the corresponding MF. The peaks were isolated and analyzed by electrophoresis (Figure 5). No differences were observed in protein composition, suggesting that the aggregates were only larger, possibly due to the higher amount of whey proteins present. This would be in full agreement with previous literature reports (Donato et al., 2007).

Figure 5 compares the protein composition of the various fractions. With the exception of milk, to allow for a straight comparison between samples, the $2 \times$ concentrations were loaded to twice the volume compared with fractions isolated from the elution of $4 \times$ supernatants. Hence, darker bands would indicate a higher concentration of protein present in the eluted fraction. The fractions analyzed from the elution of $4 \times$ supernatants presented more intense bands than those from the $2 \times$ supernatants, indicating the presence of

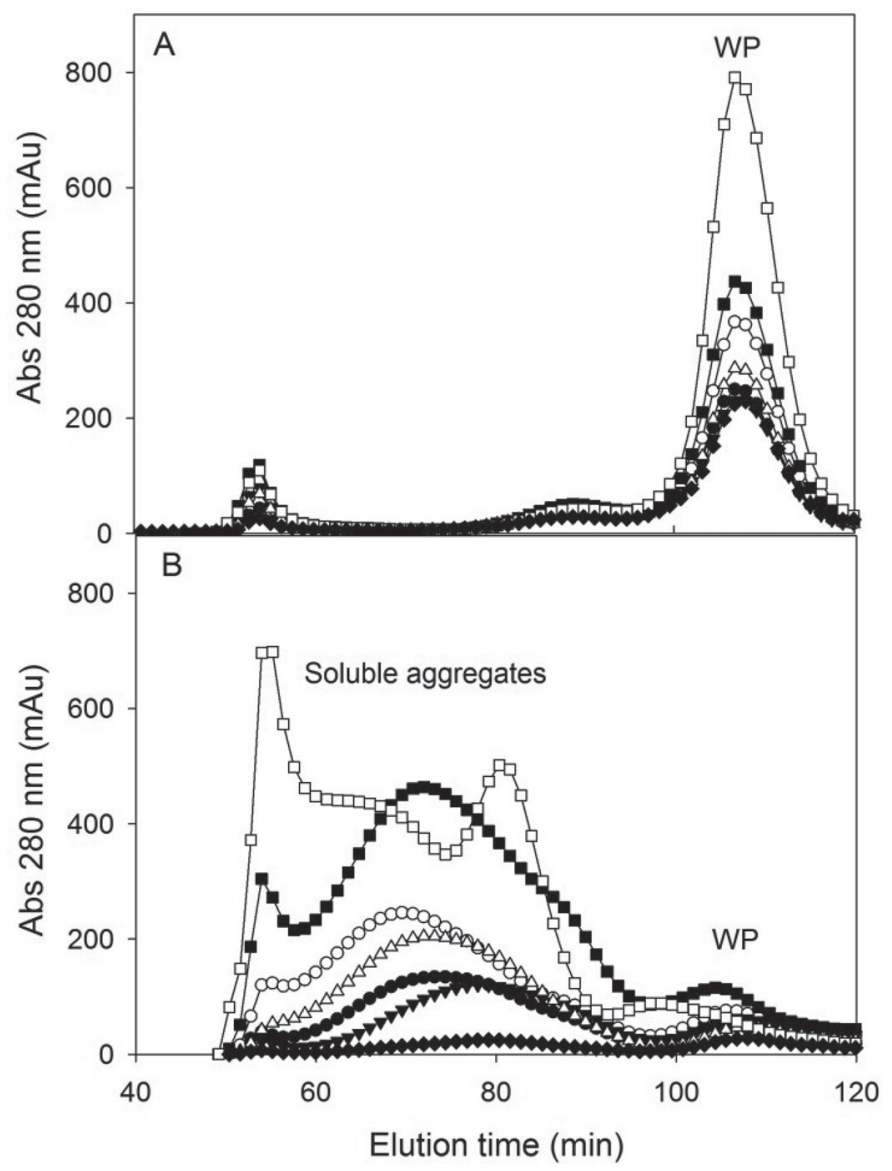

Figure 4. Size exclusion chromatography of the centrifugal supernatants of original concentrates (A) and after heating at $120^{\circ} \mathrm{C}$ for 10 $\min (\mathrm{B})$. Milk; $2 \times \mathrm{MF} ; \bigcirc 2 \times \mathrm{UF} ; \mathbf{\nabla} 4 \times \mathrm{MFD} ; \Delta 4 \times \mathrm{UFD} ; \mathbf{\square} 4 \times \mathrm{MF}$; $\square 4 \times$ UF. Abs $=$ absorbance; WP $=$ whey proteins. Microfiltered milk $2 \times$ and $4 \times$ concentrated $(2 \times \mathrm{MF} ; 4 \times \mathrm{MF})$; UF milk $2 \times$ and $4 \times$ concentrated $(2 \times \mathrm{UF} ; 4 \times \mathrm{UF})$; and $4 \times \mathrm{MF}$ and $\mathrm{UF}$ rediluted to $2 \times$ with $\mathrm{UF}$ permeate $(4 \times \mathrm{MFD} ; 4 \times \mathrm{UFD})$. 


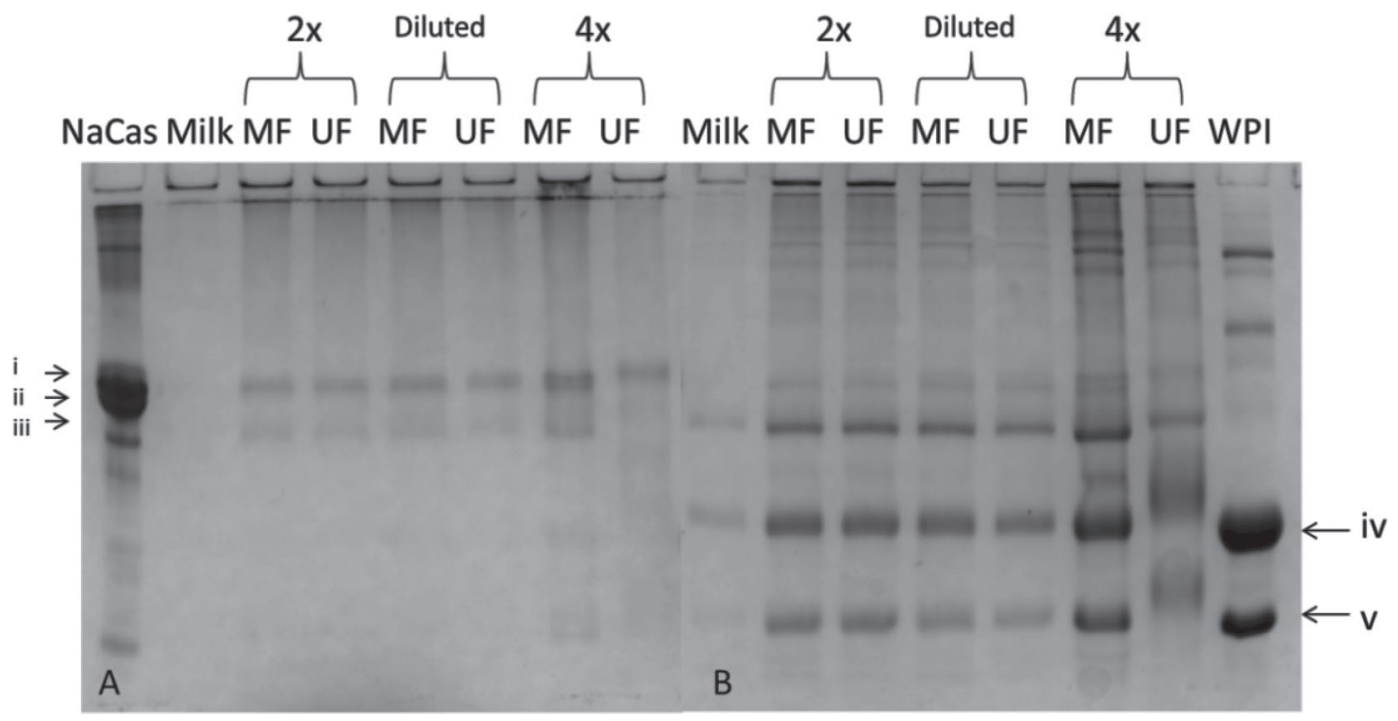

Figure 5. Sodium dodecyl sulfate-PAGE patterns under nonreducing (A) and reducing conditions (B) of heated samples serum collected from the size exclusion chromatography column from 60 to $90 \mathrm{~min}$. The bands in the gels are identified as (i) $\alpha_{\mathrm{S}}-\mathrm{CN}$, (ii) $\beta-\mathrm{CN}$, (iii) $\kappa-\mathrm{CN}$, (iv) $\beta$-LG, and (v) $\alpha$-LA. MF = microfiltered; NaCas = sodium caseinate; WPI $=$ whey protein isolate.

a higher amount of aggregates after heating. By the differences between the nonreducing and the reducing gels, it is possible to observe that whey proteins are mainly aggregated with other proteins forming soluble protein complexes. The electrophoretic analysis under reducing conditions clearly revealed that the whey proteins formed complexes with $\kappa-\mathrm{CN}$ and $\alpha-\mathrm{CN}$.

\section{CONCLUSIONS}

Fresh milk protein concentrates (UF) and micellar casein concentrates (MF) do not show the same heat stability behavior or similar physical and chemical characteristics after heat treatment at $120^{\circ} \mathrm{C}$ for 10 min. The fresh retentates analyzed showed good heat stability and heat coagulation $>30 \mathrm{~min}$. The results demonstrate that it may be possible to modulate the heat stability of concentrates by carefully controlling the composition of the soluble phase during membrane filtration. All samples showed comparable $\mathrm{pH}$ values and soluble calcium and phosphate concentrations. The results show for the first time that it is not necessary to fully deplete milk concentrates of whey proteins to maintain high heat stability, although the amount of whey protein present will affect the composition of the soluble aggregates and, importantly, retain the nutritional value of the whey proteins.

\section{ACKNOWLEDGMENTS}

The authors thank the Canadian Natural Sciences and Engineering Research Council (Ottawa, CA) for funding this work and the Brazilian National Council for Scientific and Technological Development (Brasilia, Brazil) for the scholarship.

\section{REFERENCES}

Agarwal, S., R. L. W. Beausire, S. Patel, and H. Patel. 2015. Innovative uses of milk protein concentrates in product development. J. Food Sci. 80(E-Suppl.1):A23-A29. https://doi.org/10.1111/1750 $-3841.12807$.

Alexander, M., M. Corredig, and D. G. Dalgleish. 2006. Diffusing wave spectroscopy of gelling food systems: The importance of the photon transport mean free path $\left(l^{*}\right)$ parameter. Food Hydrocolloid. 20(2-3 SPEC. ISS.):325-331. https://doi.org/10.1016/j.foodhyd .2005.02.021.

Alexander, M., and D. G. Dalgleish. 2005. Interactions between denatured milk serum proteins and casein micelles studied by diffusing wave spectroscopy. Langmuir 21:11380-11386. https://doi.org/10 .1021/la0519958.

Anema, S. G. 2009. The whey proteins in milk: Thermal denaturation, physical interactions and effects on the functional properties of milk. Pages 239-282 in Milk Proteins: From Expression to Food. A. Thompsom, M. Boland, and H. Singh, ed. Academic Press, Cambridge, MA.

Anema, S. G., K. L. Siew, and H. Klostermeyer. 2006. Effect of protein, nonprotein-soluble components, and lactose concentrations on the irreversible thermal denaturation of $\beta$-lactoglobulin and $\alpha$-lactalbumin in skim milk. J. Agric. Food Chem. 54:7339 7348. https://doi.org/10.1021/jf061508+.

Beliciu, C. M., A. Sauer, and C. I. Moraru. 2012. The effect of commercial sterilization regimens on micellar casein concentrates. J. Dairy Sci. 95:5510-5526. https://doi.org/10.3168/jds.2011-4875.

Dalgleish, D. G., and M. Corredig. 2012. The structure of the casein micelle of milk and its changes during processing. Annu. Rev. Food Sci. Technol. 3:449-467. https://doi.org/10.1146/annurev-food $-022811-101214$.

de Kort, E., M. Minor, T. Snoeren, T. Van Hooijdonk, and E. Van der Linden. 2012. Effect of calcium chelators on heat coagulation and heat-induced changes of concentrated micellar casein solutions: 
The role of calcium-ion activity and micellar integrity. Int. Dairy J. 26:112-119. https://doi.org/10.1016/j.idairyj.2012.03.014.

Donato, L., and D. G. Dalgleish. 2006. Effect of the $\mathrm{pH}$ of heating on the qualitative and quantitative compositions of the sera of reconstituted skim milks and on the mechanisms of formation of soluble aggregates. J. Agric. Food Chem. 54:7804-7811.

Donato, L., F. Guyomarc'h, S. Amiot, and D. G. Dalgleish. 2007. Formation of whey protein/ $\kappa$-casein complexes in heated milk: Preferential reaction of whey protein with $\kappa$-casein in the casein micelles. Int. Dairy J. 17:1161-1167. https://doi.org/10.1016/j.idairyj.2007 .03.011.

Eshpari, H., P. S. Tong, and M. Corredig. 2014. Changes in the physical properties, solubility, and heat stability of milk protein concentrates prepared from partially acidified milk. J. Dairy Sci. 97:7394-7401. https://doi.org/10.3168/jds.2014-8609.

Ferrer, M. A., M. Alexander, and M. Corredig. 2011. Does ultrafiltration have a lasting effect on the physico-chemical properties of the casein micelles? Dairy Sci. Technol. 91:151-170. https://doi.org/ 10.1007/s13594-011-0002-0.

Gaucheron, F. 2005. The minerals of milk. Reprod. Nutr. Dev. 45:473483. https://doi.org/10.1051/rnd:2005030

Guyomarc'h, F., A. J. R. Law, and D. G. Dalgleish. 2003. Formation of soluble and micelle-bound protein aggregates in heated milk. J. Agric. Food Chem. 51:4652-4660. https://doi.org/10.1021/ jf0211783.

Li, Y., and M. Corredig. 2014. Calcium release from milk concentrated by ultrafiltration and diafiltration. J. Dairy Sci. 97:5294-5302. https://doi.org/10.3168/jds.2013-7567.

Li, Y., D. Dalgleish, and M. Corredig. 2015. Influence of heating treatment and membrane concentration on the formation of soluble aggregates. Food Res. Int. 76:309-316. https://doi.org/10.1016/j .foodres.2015.06.016.

Nair, P. K., M. Alexander, D. Dalgleish, and M. Corredig. 2014 Physico-chemical properties of casein micelles in unheated skim milk concentrated by osmotic stressing: Interactions and changes in the composition of the serum phase. Food Hydrocoll. 34:46-53. https://doi.org/10.1016/j.foodhyd.2013.01.001.

Nair, P. K., D. G. Dalgleish, and M. Corredig. 2013. Colloidal properties of concentrated heated milk. Soft Matter 9:3815-3824. https://doi.org/10.1039/c2sm27540f.
Nelson, B. K., and D. M. Barbano. 2005. A microfiltration process to maximize removal of serum proteins from skim milk before cheese making. J. Dairy Sci. 88:1891-1900. https://doi.org/10.3168/jds .S0022-0302(05)72865-4.

Nicolai, T. 2007. Food characterisation using scattering methods. Pages 288-310 in Understanding and Controlling the Microstructure of Complex Foods. D. J. McClements, ed. Woodhead Publishing Limited, Cambridge, UK.

O'Connell, J. E., and P. F. Fox. 2003. Heat-induced coagulation of milk. Pages 879-946 in Advanced dairy chemistry-Vol. 1. Proteins Part B. P. F. Fox and P. L. H. McSweeney, ed. Kluwer Academic/ Plenum Publishers, New York, NY.

Sandra, S., C. Cooper, M. Alexander, and M. Corredig. 2011. Coagulation properties of ultrafiltered milk retentates measured using rheology and diffusing wave spectroscopy. Food Res. Int. 44:951-956. https://doi.org/10.1016/j.foodres.2011.02.018.

Sauer, A., and C. I. Moraru. 2012. Heat stability of micellar casein concentrates as affected by temperature and $\mathrm{pH}$. J. Dairy Sci 95:6339-6350. https://doi.org/10.3168/jds.2012-5706.

Sikand, V.. P. S. Tong, and J. Walker. 2013. Effect of adding salt during the diafiltration step of milk protein concentrate powder manufacture on mineral and soluble protein composition. Dairy Sci. Technol. 93:401-413. https://doi.org/10.1007/s13594-013-0110-0.

Singh, H. 2004. Heat stability of milk. Int. J. Dairy Technol. 57:111119. https://doi.org/10.1111/j.1471-0307.2004.00143.x.

Singh, H., and P. Havea. 2003. Thermal denaturation, aggregation and gelation of whey proteins. Pages 1261-1287 in Advanced dairy chemistry-Vol. 1. Proteins Part B. P. F. Fox and P. L. H. Mcsweeney, ed. Kluwer Academic/Plenum Publishers, New York, NY.

Walstra, P., J. T. M. Wouters, and T. J. Geurts. 2006. Milk properties. Pages 159-174 in Dairy Science and Technology. P. Walstra, J. T. M. Wouters, and T. J. Geurts, ed. CRC Press, Boca Raton, FL.

Zhao, Z., and M. Corredig. 2015. Changes in the physico-chemical properties of casein micelles in the presence of sodium chloride in untreated and concentrated milk protein. Dairy Sci. Technol. 95:87-99. https://doi.org/10.1007/s13594-014-0200-7. 